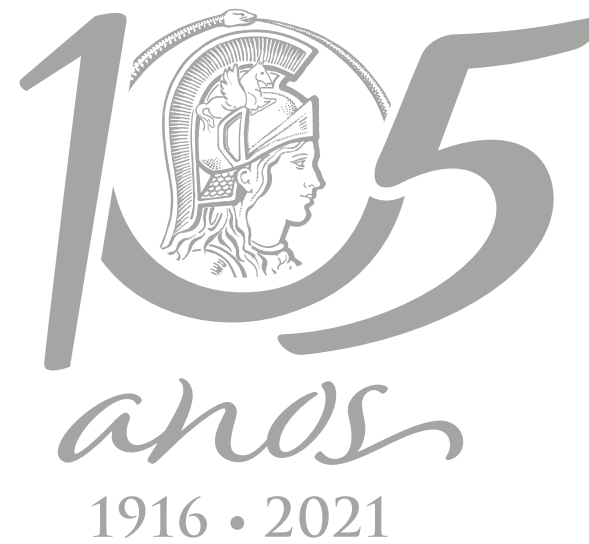

$1916 \cdot 2021$

\title{
Synthesis of new 1,4-disubstituted 1,2,3-triazoles using the CuAAC reaction and determination of their antioxidant activities
}

\author{
JOSEFA A. DA CUNHA LIMA, JADSON DE FARIAS SILVA, COSME S. SANTOS, \\ RODRIGO R.A. CAIANA, MARCÍLIO M. DE MORAES, CLAUDIO A.G. DA CÂMARA \& \\ JULIANO C.R. FREITAS
}

\begin{abstract}
This study describes the synthesis and antioxidant activity of new 1,4-disubstituted 1,2,3-triazoles. These compounds were generated semi-synthetically using the $\mathrm{Cu}(\mathrm{I})$-catalysed azide-alkyne cycloaddition (CUAAC) reaction between ethyl 2-azidoacetate and terminal acetylenes derived from the natural products carvacrol, eugenol, isovanillin, thymol and vanillin. The products were obtained at 50 to $80 \%$ yield and characterised through several spectrographic techniques. Antioxidant activity was assayed using 2,2-diphenyl-1-picrylhydrazyl (DPPH) and 2,2'-azino-bis(3ethylbenzothiazoline-6-sulphonic acid) (ABTS). The products exhibited moderate antioxidant activity, with ethyl 2-(4-((4-formyl-2-methoxyphenoxy)methyl)-1H-1,2,3triazol-1-yl) acetate showing the highest antioxidant capacity $\left(\mathrm{EC}_{50}=75.5 \mu \mathrm{g} / \mathrm{mL}\right)$ among the generated 1,4-disubstituted 1,2,3-triazoles. In conclusion, the generation of these compounds opens new possibilities for the development of new antioxidant agents.
\end{abstract}

Key words: Antioxidant activity, Free radicals, 1,2,3-Triazole, CuAAC Reaction.

\section{INTRODUCTION}

Oxidative stress plays a crucial role in the development of age-related diseases as well as diabetes, dementia, cancer, atherosclerosis, vascular disease, obesity, osteoporosis, and metabolic syndrome (Tan et al. 2018). Accordingly, the discovery and development of protective agents against oxidative stress are of great interest. One possible approach for the development of new antioxidant agents involves the use of virtual screening through molecular docking with the enzyme superoxide dismutase (SOD) (Gurunanjappa et al. 2016, Kumar et al. 2016, Hatai \& Banerjee 2019). SOD acts as an endogenous antioxidant defence system, converting hydrogen peroxide-derived superoxide radicals to water and oxygen to neutralise these species and thus prevent their harmful effects on cellular components (Moloney \& Cotter 2017, Rahal et al. 2014).

Among the classes of organic compounds that enhance SOD activity, 1,2,3-triazoles stand out (Biagi et al. 1990, Satapute et al. 2019, Zhang et al. 2016). 1,2,3-triazoles are heterocyclic compounds that are easily prepared through a $\mathrm{Cu}(\mathrm{I})$-catalysed azide-alkyne cycloaddition (CUAAC) reaction. These compounds serve as analogues of various biological functional groups acting as hydrogen bond donors and acceptors (Dheer et al. 2017, Agalave et al. 2011, Santos et al. 2020). The objective of this work was to synthesise new molecules containing 
the 1,2,3-triazole scaffold and evaluate their antioxidant potential.

\section{MATERIALS AND METHODS}

\section{Chemicals and materials}

In the synthesis of compounds 4a-e: carvacrol (CAS number 499-75-2, Sigma-Aldrich, 99\%), eugenol (CAS number 97-53-0, ReagentPlus ${ }^{\circledR}$, 99\%), isovanillin (CAS number 621-59-0, Sigma Aldrich, 99\%), propargyl bromide solution (CAS number 106-96-7, purum, 80\% in toluene), potassium carbonate anhydrous (CAS number 584-08-7, ACS reagent, $\geq 99 \%$ ), thymol (CAS number 499-75-2, Sigma-Aldrich, 98\%) and vanillin (CAS number 121-33-5, ReagentPlus ${ }^{\circledR}$, 99\%), were used to prepare terminal alkynes. Ethyl bromoacetate (CAS number 105-362, Sigma-Aldrich, 98\%), Copper(II) sulfate pentahydrate $\mathrm{CuSO}_{4} \cdot 5 \mathrm{H}_{2} \mathrm{O}$, CAS number 7758 99-8, ACS reagent, $\geq 98.0 \%)$, Sodium azide $\left(\mathrm{NaN}_{3}\right.$, CAS number 26628-22-8, ReagentPlus $\left.{ }^{\circledR}, \geq 99.5 \%\right)$, (+)-Sodium L-ascorbate (CAS number 134-03-2, Sigma-Aldrich, $\geq 99.0 \%$ ), were used to prepare compounds $\mathbf{2}$ and $\mathbf{5 a - e}$. The reactions were monitored by thin-layer chromatography (TLC) using silica gel plates (with fluorescent indicator $\mathrm{F}_{254}$ ). TLC plates were visualized using UV light. The purification step was performed by liquid chromatography on a glass column using silica gel 60 (70-230 mesh) as the stationary phase, and the hexane and ethyl acetate solvents in different proportions as mobile phase. Spectral analyzes of the synthesized compounds were obtained using the Fourier transform infrared spectrophotometer (Spectrum 400 FT-IR / FTNIR Spectrometer model PerkinElmer), the ${ }^{1} \mathrm{H}$ NMR and ${ }^{13} \mathrm{C}$ NMR spectra were obtained on a Varian Unity Plus spectrometer 300 and 400 $\mathrm{MHz}$ with the chloroform-d (CAS number 86549-6, Sigma-Aldrich, 99.96 atom \% D) solvent and tetramethylsilane was used as an internal standard. The carbon, hydrogen and nitrogen contents of the compounds were determined by the Dynamic Flash Combustion technique, in a CHNS-O elementary analyzer, CE Instruments, model EA 1110. The melting points ( $\mathrm{mp}$ ) were obtained using a Eletrothermal 9100 melting point apparatus and are not corrected.

\section{Procedure for the synthesis of ethyl 2-azidoacetate (2)}

The ethyl 2-azidoacetate (2) was prepared following the procedure of Liao et al. (2017). The ethyl 2-bromoacetate (1) (0.526 g, $3.15 \mathrm{mmol}$ ) was dissolved in $3 \mathrm{~mL}$ of acetone. The solution was cooled to $0{ }^{\circ} \mathrm{C}$ and a solution of sodium azide $(0.683 \mathrm{~g}, 10.5 \mathrm{mmol})$ of water $(3.0 \mathrm{~mL})$ was slowly added under constant stirring. After the mixture was heated to $60{ }^{\circ} \mathrm{C}$ and stirred at that temperature for $12 \mathrm{~h}$. The reaction mixture was diluted with dichloromethane $(30 \mathrm{~mL})$ and washed with water $(4 \times 30 \mathrm{~mL})$. The combined organic layers were dried over $\mathrm{Na}_{2} \mathrm{SO}_{4}$, and concentrated in vacuum. The desired ethyl 2-azidoacetate (2) was obtained without further purification. The structure of compound (2) is supported by the following data. (Supplementary Material - Figures S1 to S2).

Ethyl 2-azidoacetate (2): Reaction time: $12 \mathrm{~h}$; colorless oil; yield $98 \%,{ }^{1} \mathrm{H}$ NMR $\left(300 \mathrm{MHz}, \mathrm{CDCl}_{3}\right)$ $\delta 1.32(\mathrm{t}, 2 \mathrm{H}, J=7.0 \mathrm{~Hz}), 4.27(\mathrm{q}, 2 \mathrm{H}, J=7.0 \mathrm{~Hz}) \cdot{ }^{13} \mathrm{C}$ $\operatorname{NMR}\left(75 \mathrm{MHz}_{\mathrm{C}} \mathrm{CDCl}_{3}\right) \delta 14.2,50.4,61.9,168.3$. This is in agreement with data previously reported (Liao et al. 2017).

\section{General procedure for the synthesis of alkynes 4a-e}

The alkynes (4a-e) were prepared following the procedure of Ferroni et al. (2017). Phenols (3a-e) (1.0 mmol) and anhydrous $\mathrm{K}_{2} \mathrm{CO}_{3}(0.276 \mathrm{~g}$, $1.5 \mathrm{mmol}$ ) were added in a $25 \mathrm{~mL}$ two-necked flask and dissolved in $10 \mathrm{~mL}$ acetone. After $10 \mathrm{~min}$, propargyl bromide ( $80 \%$ in toluene, 0.129 
$\mathrm{mL}, 1.5 \mathrm{mmol}$ ) was slowly added and the reaction mixture was refluxed under $\mathrm{N}_{2}$ atmosphere for $10 \mathrm{~h}$. Then the mixture was diluted with water $(20 \mathrm{~mL})$ and extracted with ethyl acetate $(3 \times 20 \mathrm{~mL})$. The combined organic phases were dried over $\mathrm{Na}_{2} \mathrm{SO}_{4}$ and the solvents were removed under reduced pressure followed by purification by flash column chromatography to yield the desired alkynes (4a-e). The structure of compound (4a-e) is supported by the following data (Figures S3 to S12).

4-isopropyl-1-methyl-2-(prop-2-yn-1-yloxy) benzene (4a): The crude product was purified by flash column chromatography, using ethyl acetate/hexane (08:92). Reaction time: $8 \mathrm{~h}$; colorless oil; yield 90\%; ${ }^{1} \mathrm{H}$ NMR $\left(400 \mathrm{MHz}, \mathrm{CDCl}_{3}\right)$ $\delta 1.23(\mathrm{~d}, 6 \mathrm{H}, J=7.2 \mathrm{~Hz}), 2.20(\mathrm{~s}, 3 \mathrm{H}), 2.48(\mathrm{t}, 1 \mathrm{H}$, J $=2.4 \mathrm{~Hz}), 2.87(\mathrm{q}, 1 \mathrm{H}, J=7.2 \mathrm{~Hz}), 4.69(\mathrm{~d}, 2 \mathrm{H}, J=2.4$ $\mathrm{Hz}), 6.77(\mathrm{~d}, 1 \mathrm{H}, J=8.0 \mathrm{~Hz}), 6.81(\mathrm{~s}, 1 \mathrm{H}), 7.05(\mathrm{~d}, 1 \mathrm{H}$, $J=7.6 \mathrm{~Hz}) ;{ }^{13} \mathrm{C}$ NMR $\left(100 \mathrm{MHz}, \mathrm{CDCl}_{3}\right) \delta 15.8,24.04$, 34.0, 55.9, 75.1, 79.1, 110.3, 119.1, 124.5, 130.6, 147.8, 155.7. This is in agreement with data previously reported (Aneja et al. 2018).

1-isopropyl-4-methyl-2-(prop-2-yn-1-yloxy) benzene (4b): The crude product was purified by flash column chromatography, using ethyl acetate/hexane (08:92). Reaction time: $10 \mathrm{~h}$; colorless oil; yield 91\%; ${ }^{1} \mathrm{H}$ NMR $\left(400 \mathrm{MHz}, \mathrm{CDCl}_{3}\right)$ $\delta 1.14(\mathrm{~d}, 6 \mathrm{H}, \mathrm{J}=7.2 \mathrm{~Hz}) ; 2.28$ (s, 3H); $2.43(\mathrm{t}, 1 \mathrm{H}, \mathrm{J}=$ $2.4 \mathrm{~Hz}) ; 3.25(\mathrm{q}, 1 \mathrm{H}, J=7.2 \mathrm{~Hz}) ; 4.64(\mathrm{~d}, 2 \mathrm{H}, J=2.4$ $\mathrm{Hz}) ; 6.72-6.75(\mathrm{~m}, 2 \mathrm{H}) ; 7.06(\mathrm{~d}, 1 \mathrm{H}, J=7.6 \mathrm{~Hz}) ;{ }^{13} \mathrm{C}$ NMR $\left(100 \mathrm{MHz} \mathrm{CDCl}_{3}\right) \delta$ 21.3, 22.8, 26.4, 56.1, 74.9, 79.1, 113.0, 122.2, 126.1, 134.7, 136.2, 154.7.

4-allyl-2-methoxy-1-(prop-2-yn-1-yloxy) benzene (4c): The crude product was purified by flash column chromatography, using ethyl acetate/hexane (10:90). Reaction time: $6 \mathrm{~h}$; yellow oil; yield $86 \%$; ${ }^{1} \mathrm{H} \mathrm{NMR}\left(400 \mathrm{MHz}, \mathrm{CDCl}_{3}\right)$ $\delta 2.49(\mathrm{t}, 1 \mathrm{H}, J=2.4 \mathrm{~Hz}), 3.34(\mathrm{~d}, 2 \mathrm{H}, J=6.8 \mathrm{~Hz})$, $3.86(\mathrm{~s}, 3 \mathrm{H}), 4.73(\mathrm{~d}, 2 \mathrm{H}, \mathrm{J}=2.4 \mathrm{~Hz}), 5.06-5.11(\mathrm{~m}$, $2 \mathrm{H}), 5.91-6.01(\mathrm{~m}, 1 \mathrm{H}), 6.72-6.74(\mathrm{~m}, 2 \mathrm{H}), 6.96(\mathrm{~m}$, $1 \mathrm{H}) ;{ }^{13} \mathrm{C}$ NMR $\left(100 \mathrm{MHz}, \mathrm{CDCl}_{3}\right) \delta 39.8,55.7,56.8$,
75.5, 78.7, 112.3, 114.6, 115.7, 120.2, 134.2, 137.4, 145.0, 149.6. This is in agreement with data previously reported (Teixeira et al. 2018).

4-methoxy-3-(prop-2-yn-1-yloxy) benzaldehyde $(\mathbf{4 d})$ : The crude product was purified by flash column chromatography, using ethyl acetate/ hexane (30:70). Reaction time: 8 h; solid, mp 71-72 o-C, yield 88\%; ${ }^{1} \mathrm{H}$ NMR $(400 \mathrm{MHz}$, $\left.\mathrm{CDCl}_{3}\right) \delta 2.53(\mathrm{t}, 1 \mathrm{H}, J=2.4 \mathrm{~Hz}), 3.95(\mathrm{~s}, 3 \mathrm{H}), 4.81(\mathrm{~d}$, $2 \mathrm{H}, J=2.4 \mathrm{~Hz}), 6.98(\mathrm{~d}, 1 \mathrm{H}, J=8.0 \mathrm{~Hz}), 7.49-7.53(\mathrm{~m}$, $2 \mathrm{H}), 9.85(\mathrm{~s}, 1 \mathrm{H}) ;{ }^{13} \mathrm{C} \mathrm{NMR}\left(100 \mathrm{MHz}, \mathrm{CDCl}_{3}\right) \delta 56.1$, 5.6, 76.4, 77.7, 110.9, 112.0, 127.2, 129.9, 147.3, 154.9, 190.6. This is in agreement with data previously reported (Hussaini et al. 2016).

3-methoxy-4-(prop-2-yn-1-yloxy) benzaldehyde (4e): The crude product was purified by flash column chromatography, using ethyl acetate/ hexane (30:70). Reaction time: 8 h; solid, mp 84-85 OC, yield 90\% ; ${ }^{1} \mathrm{H}$ NMR $(400 \mathrm{MHz}$, $\left.\mathrm{CDCl}_{3}\right) \mathrm{d} 2.58(\mathrm{t}, 1 \mathrm{H}, \mathrm{J}=2.4 \mathrm{~Hz}), 3.94(\mathrm{~s}, 3 \mathrm{H}), 4.86(\mathrm{~d}$, $2 \mathrm{H}, J=2.4 \mathrm{~Hz}), 7.14(\mathrm{~d}, 1 \mathrm{H}, J=8.0 \mathrm{~Hz}), 7.44(\mathrm{~d}, 1 \mathrm{H}, J=$ $1.6 \mathrm{~Hz}), 7.47(\mathrm{dd}, 1 \mathrm{H}, J=1.6$ and $7.6 \mathrm{~Hz}), 9.88(\mathrm{~s}, 1 \mathrm{H})$; ${ }^{13} \mathrm{C} \mathrm{NMR}\left(100 \mathrm{MHz}, \mathrm{CDCl}_{3}\right)$ d 55.9, 56.5, 76.6, 77.4, $109.5,112.6,126.2,130.9,149.9,152.1,190.8$. This is in agreement with data previously reported (Fong et al. 2019).

\section{General procedure for the synthesis of triazoles 5a-e}

The triazoles (5a-e) were prepared following the procedure described by Rostovtsev et al. (2002). The alkyne (4a-e) $(1.0 \mathrm{mmol})$ and ethyl 2-azidoacetate (2) $(0.14 \mathrm{~g}, 1.1 \mathrm{mmol})$ were added to a 1:1 mixture of water and tert-butyl alcohol $(4 \mathrm{~mL})$. Sodium ascorbate $(0.1 \mathrm{mmol}$, in $300 \mu \mathrm{L}$ of water) was added, followed by copper(II) sulfate pentahydrate $(0.01 \mathrm{mmol}$, in $100 \mu \mathrm{L}$ of water). The reaction mixture was stirred vigorously at room temperature $(25 \pm 3$ oC) and monitored by TLC until the reagents were completely consumed. The reaction the mixture was extracted with $50 \mathrm{~mL}$ of dichloromethane and washed with 
water $(3 \times 30 \mathrm{~mL})$. The combined organic phases were dried over $\mathrm{Na}_{2} \mathrm{SO}_{4}$ and the solvents were removed under reduced pressure followed by purification by flash column chromatography to yield the desired triazoles (5a-e). The structure of compound $\mathbf{5 a - e}$ is supported by the following data (Figures S13 to S22).

Ethyl 2-(4-((5-isopropyl-2-methylphenoxy) methyl)-1H-1,2,3-triazol-1-yl)acetate (5a): The crude product was purified by flash column chromatography, using ethyl acetate/hexane (40:60). Reaction time: 2 h; white solid; mp 86-87 ${ }^{\circ} \mathrm{C}$; yield 70\%; IR ( $\mathrm{KBr}$ pellet) $\mathrm{v}_{\max } 3137,2961,1755$, 1611, $1211 \mathrm{~cm}^{-1} ;{ }^{1} \mathrm{H}$ NMR (400 MHz, $\left.\mathrm{CDCl}_{3}\right)$ d 1.24 (d, $6 \mathrm{H}, J=6.8 \mathrm{~Hz}), 1.30(\mathrm{t}, 3 \mathrm{H}, J=7.6 \mathrm{~Hz}), 2.19(\mathrm{~s}, 3 \mathrm{H})$, 2.83-2.90 (m, 1H), $4.27(\mathrm{q}, 2 \mathrm{H}, J=7.2 \mathrm{~Hz}), 5.16(\mathrm{~s}$, $2 \mathrm{H}), 5.26(\mathrm{~s}, 2 \mathrm{H}), 6.77(\mathrm{~d}, 1 \mathrm{H}, J=7.2 \mathrm{~Hz}), 6.83(\mathrm{~s}, 1 \mathrm{H})$, $7.06(\mathrm{~d}, 1 \mathrm{H}, J=7.2 \mathrm{~Hz}), 7.73(\mathrm{~s}, 1 \mathrm{H}) ;{ }^{13} \mathrm{C}$ NMR $(100$ $\left.\mathrm{MHz}, \mathrm{CDCl}_{3}\right)$ d 13.9, 15.7, 24.0, 34.0, 50.8, 62.3, 62.3, 110.0, 118.6, 123.6, 124.1, 130.5, 145.3, 147.9, 156.2, 166.1; Anal. C, 64.21\%; H, $7.37 \%$; N, 13.01\%. calcd $\mathrm{C}_{17} \mathrm{H}_{23} \mathrm{~N}_{3} \mathrm{O}_{3}: \mathrm{C}, 64.33 \% ; \mathrm{H}, 7.30 \% ; \mathrm{N}, 13.24 \%$.

Ethyl 2-(4-((2-isopropyl-5-methylphenoxy) methyl)-1H-1,2,3-triazol-1-yl)acetate (5b): The crude product was purified by flash column chromatography, using ethyl acetate/hexane (40:60). Reaction time: $2.3 \mathrm{~h}$; white solid; mp 6162 oC; yield 60\%; IR ( $\mathrm{KBr}$ pellet) $\mathrm{v}_{\max } 3131,2955$, 1749, 1613, $1210 \mathrm{~cm}^{-1} ;{ }^{1} \mathrm{H}$ NMR $\left(400 \mathrm{MHz}, \mathrm{CDCl}_{3}\right) \mathrm{d}$ $1.19(\mathrm{~d}, 6 \mathrm{H}, J=7.2 \mathrm{~Hz}), 1.30(\mathrm{t}, 3 \mathrm{H}, J=6.8 \mathrm{~Hz}), 2.32$ (s, 3H), 3.25-3.32 (m, 1H), 4.27 (q, 2H, J = 7.2 Hz), 5.17 (s, 2H), $5.24(\mathrm{~s}, 2 \mathrm{H}), 6.77-6,79(\mathrm{~m}, 2 \mathrm{H}), 7.11(\mathrm{~d}, 1 \mathrm{H}$, $J=7.6 \mathrm{~Hz}), 7.73(\mathrm{~s}, 1 \mathrm{H}) ;{ }^{13} \mathrm{C} \mathrm{NMR}\left(100 \mathrm{MHz}, \mathrm{CDCl}_{3}\right)$ d 14.0, 21.3, 22.7, 26.6, 50.9, 62.4, 62.4, 112.7, 121.8, 123.6, 126.0, 134.2, 136.4, 145.3, 155.2, 166.1; Anal. C, 64.29\%; $\mathrm{H}, 7.21 \%$;, $13.05 \%$. calcd $\mathrm{C}_{17} \mathrm{H}_{23} \mathrm{~N}_{3} \mathrm{O}_{3}: \mathrm{C}$, 64.33\%; H, 7.30\%; N, 13.24\%.

Ethyl 2-(4-((4-allyl-2-methoxyphenoxy) methyl)-1H-1,2,3-triazol-1-yl)acetate (5c): The crude product was purified by flash column chromatography, using ethyl acetate/hexane (45:55). Reaction time: 0,5 h; white solid; mp 93
oC; yield 80\%; IR ( $\mathrm{KBr}$ pellet) $\mathrm{v}_{\max } 3138,3079,2996$, $1753,1638,1518,1209,1038 \mathrm{~cm}^{-1} ;{ }^{1} \mathrm{H}$ NMR $(400 \mathrm{MHz}$, $\left.\mathrm{CDCl}_{3}\right)$ d $1.27(\mathrm{t}, 3 \mathrm{H}, J=7.3 \mathrm{~Hz}), 3.30(\mathrm{~d}, 2 \mathrm{H}, J=6.8$ $\mathrm{Hz}), 3.83(\mathrm{~s}, 3 \mathrm{H}), 4.21-4.26(\mathrm{q}, 2 \mathrm{H}, \mathrm{J}=7.3 \mathrm{~Hz}), 5.03-$ $5.08(\mathrm{~m}, 2 \mathrm{H}), 5.12(\mathrm{~s}, 2 \mathrm{H}), 5.27(\mathrm{~s}, 2 \mathrm{H}), 5.90-5.97(\mathrm{~m}$, $1 \mathrm{H}), 6.67-6.71(\mathrm{~m}, 2 \mathrm{H}), 6.94(\mathrm{~d}, 1 \mathrm{H}, J=7.6 \mathrm{~Hz}), 7.76$ $(\mathrm{s}, 1 \mathrm{H}) ;{ }^{13} \mathrm{C} \mathrm{NMR}\left(100 \mathrm{MHz}, \mathrm{CDCl}_{3}\right) \delta 13.9,39.7,50.8$, 55.7, 62.3, 63.2, 112.2, 114.4, 115.6, 120.4, 124.2, 133.7, 137.4, 144.8, 145.8, 149.4, 166.0; Anal. C, 61.73\%; H, $6.37 \% ; \mathrm{N}, 12.80 \%$. calcd for $\mathrm{C}_{17} \mathrm{H}_{21} \mathrm{~N}_{3} \mathrm{O}_{4}$ : C, $61.62 \%$; $\mathrm{H}, 6.39 \% ; \mathrm{N}, 12.68 \%$.

Ethyl 2-(4-((5-formyl-2-methoxyphenoxy) methyl)-1H-1,2,3-triazol-1-yl)acetate (5d): The crude product was purified by flash column chromatography, using ethyl acetate/hexane (65:35). Reaction time: $0.5 \mathrm{~h}$; white solid; mp 126127 ㅇ; yield 50\%; IR ( $\mathrm{KBr}$ pellet) $\mathrm{v}_{\max } 3146,2997$, 1742, 1687, $1222 \mathrm{~cm}^{-1}$; ${ }^{1} \mathrm{H}$ NMR $\left(400 \mathrm{MHz}, \mathrm{CDCl}_{3}\right)$ d $1.27(\mathrm{t}, 3 \mathrm{H}, J=7.2 \mathrm{~Hz}), 3.91(\mathrm{~s}, 3 \mathrm{H}), 4.25(\mathrm{q}, 2 \mathrm{H}$, J $=7.2 \mathrm{~Hz}), 5.14(\mathrm{~s}, 2 \mathrm{H}), 5.32(\mathrm{~s}, 2 \mathrm{H}), 6.98(\mathrm{~d}, 1 \mathrm{H}, \mathrm{J}=$ $8.4 \mathrm{~Hz}), 7.49(\mathrm{dd}, 1 \mathrm{H}, J=8.4$, and $2.0 \mathrm{~Hz}), 7.54(\mathrm{~d}$, $1 \mathrm{H}, J=1.6 \mathrm{~Hz}), 7.80(\mathrm{~s}, 1 \mathrm{H}), 9.83(\mathrm{~s}, 1 \mathrm{H}) ;{ }^{13} \mathrm{C} \mathrm{NMR}$ $\left(100 \mathrm{MHz}, \mathrm{CDCl}_{3}\right)$ d 13.9, 50.8, 56.0, 62.4, 62.8, 110.9, 112.3, 124.4, 126.6, 129.9, 143.7, 148.1, 154.9, 166.0, 190.6; Anal. C, 56.21\%; H, $5.33 \%$; N, 13.05\%. calcd $\mathrm{C}_{15} \mathrm{H}_{17} \mathrm{~N}_{3} \mathrm{O}_{5}: \mathrm{C}, 56.42 \% ; \mathrm{H}, 5.37 \% ; \mathrm{N}, 13.16 \%$.

Ethyl 2-(4-((4-formyl-2-methoxyphenoxy) methyl)-1H-1,2,3-triazol-1-yl)acetate (5e): The crude product was purified by flash column chromatography, using ethyl acetate/hexane (65:35). Reaction time: $0.7 \mathrm{~h}$; white solid; mp 144145 oC; yield 70\%; IR ( $\mathrm{KBr}$ pellet) $\mathrm{v}_{\max } 3140,2969$, 1742, 1691, 1222 $\mathrm{cm}^{-1}$; RMN ${ }^{1} \mathrm{H}\left(400 \mathrm{MHz}, \mathrm{CDCl}_{3}\right) \mathrm{d}$ $1.26(\mathrm{t}, 3 \mathrm{H}, J=7.2 \mathrm{~Hz}), 3.89(\mathrm{~s}, 3 \mathrm{H}), 4.24(\mathrm{q}, 2 \mathrm{H}, J=7.2$ $\mathrm{Hz}), 5.13(\mathrm{~s}, 2 \mathrm{H}), 5.37(\mathrm{~s}, 2 \mathrm{H}), 7.20(\mathrm{~d}, 1 \mathrm{H}, \mathrm{J}=8.0 \mathrm{~Hz})$, 7.40 (m, 2H), 7.81 (s, 1H), $9.82(\mathrm{~s}, 1 \mathrm{H}) ;{ }^{13} \mathrm{C}$ NMR (100 $\mathrm{MHz}_{2} \mathrm{CDCl}_{3}$ ) d 13.9, 50.8, 55.9, 62.4, 62.7, 62.7, 109.2, 112.5, 124.5, 126.6, 130.5, 143.6, 149.8, 152.9, 165.9, 190.8; Anal. C, 56.65\%; H, $5.18 \%$; N, 13.11\%. calcd $\mathrm{C}_{15} \mathrm{H}_{17} \mathrm{~N}_{3} \mathrm{O}_{5}: \mathrm{C}, 56.42 \% ; \mathrm{H}, 5.37 \% ; \mathrm{N}, 13.16 \%$. 


\section{Evaluation of the antioxidant activity of compounds 5a-e}

The evaluation of antioxidant activity was performed according to two methodologies which are based on the capture of DPPH radicals (2,2-diphenyl-1-picrylhydrazyl) and 2,2'-azinobis(3-ethylbenzothiazoline-6-sulphonic acid) (ABTS). The DPPH free radical scavenging test was carried out according to the methodology described by Silva et al. (2006). In this assay, ascorbic acid was used as a positive control. In the second test performed, which was based on the capture the radical ABTS, the methodology described by Re et al. (1999) was used, in which (+)-6-hydroxy-2,5,7,8-tetramethylchroman2-carboxylic acid (Trolox) as a positive control. Compounds 5a-e were tested in both methodologies at concentrations of 10 to 500 $\mu \mathrm{g} / \mathrm{mL}$ and all tests were performed in triplicate. Antiradical efficiency was established using linear regression analysis in the 95\% confidence interval $(P<0.05)$ obtained by the GraphPad Prism 5.0 statistical program. The results were expressed using the $\mathrm{EC}_{50}$ value, which represents the concentration of the sample necessary to sequester $50 \%$ of the DPPH radicals or the ABTS radical.

\section{RESULTS AND DISCUSSION}

\section{Synthesis and characterisation of target compounds}

1,4-Disubstituted 1,2,3-triazoles were obtained in three steps by incorporating the 1,2,3-triazole scaffold into the natural products carvacrol (3a), thymol (3b), eugenol (3c), vanillin (3d), and isovanillin (3e), as shown in Figure 1. First, ethyl 2-azidoacetate (2) was prepared by azidation of ethyl 2-bromoacetate (1). In parallel, the terminal alkynes 4a-e were prepared by the propargylation reaction of natural products 3a-e. Subsequently, the CuAAC reaction was performed to obtain the desired compounds 5a-e.

The first step provided compound $\mathbf{2}$ with $98 \%$ yield after $12 \mathrm{~h}$. Spectroscopic data for compound $\mathbf{2}$ were consistent with those described by Liao et al. (2017). The propargylation reaction of compounds 3 a-e provided terminal alkynes 4 a-e. These propargylated derivatives were obtained in high yields after reaction times ranging from 6 to $10 \mathrm{~h}$ after chromatographic purification (Figure 2). Compounds 4a-e were obtained without significant differences in yield. Additionally, the structural characterisation of compounds 4 a-e was consistent with reported

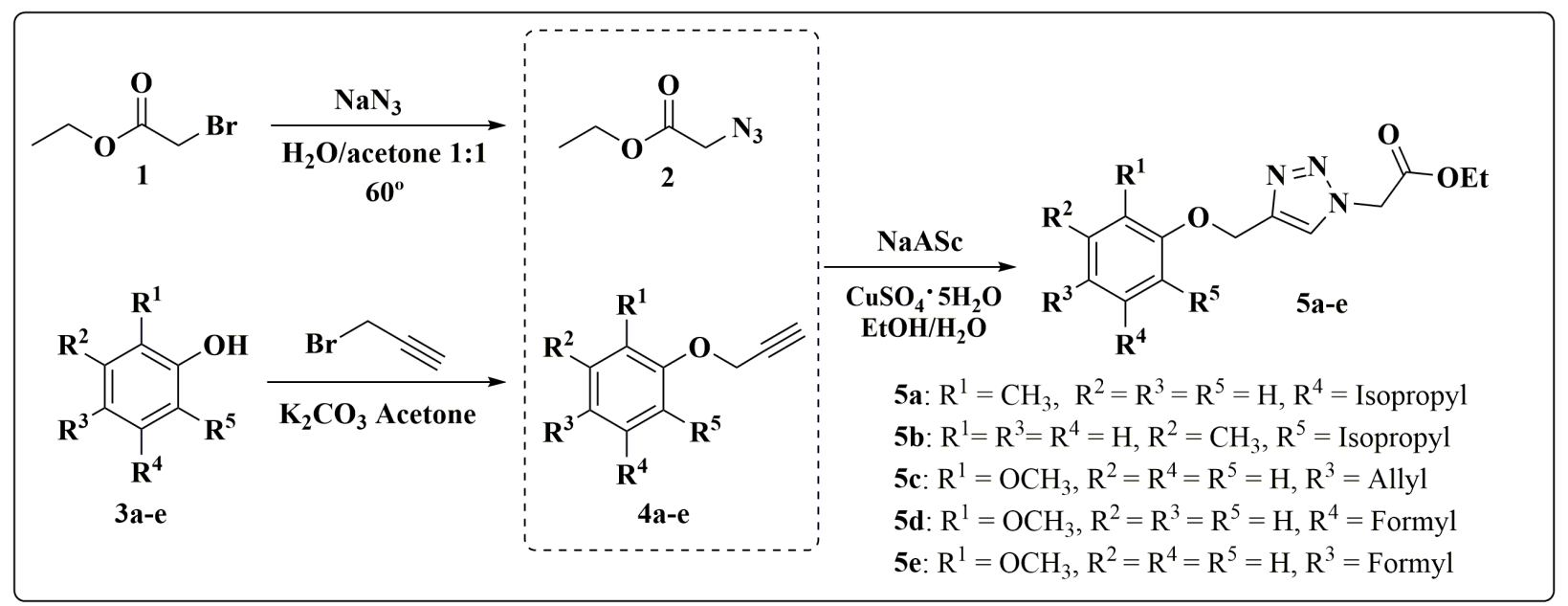

Figure 1. Reaction steps involved in the preparation of the new 1,4-disubstituted 1,2,3-triazoles 5a-e. 
data (Liao et al. 2017, Aneja et al. 2018, Teixeira et al. 2018, Hussaini et al. 2016, Fong et al. 2019). The final step resulted in compounds $\mathbf{5 a - e}$ in yields ranging from 50 to $80 \%$ after chromatographic purification (Figure 3). In general, the CuAAC reaction time and yield varied significantly, depending on the substrate used. Studies have shown that deprotonation of the terminal alkyne to form the copper(I) acetylide is an important step in this reaction, and electron-withdrawing groups are expected to both increase the acidity of the terminal alkyne hydrogen and the reactivity of the corresponding alkyne (Iacobucci et al. 2015, Zhang et al. 2016). However, due to the presence of an $s p^{3}$-hybridised carbon between the oxygen of the aromatic ring and the reaction site $(\mathrm{C} \equiv \mathrm{C}-\mathrm{H})$ in compounds $4 \mathrm{a}$ e, resonance does not occur, and the weak inductive effect caused by removing electrons has little influence on product formation $\mathbf{5 a - e}$. Additionally, compound $\mathbf{5 b}$ required a longer reaction time than compound $\mathbf{5 a}$, which was attributed to steric hindrance caused by the isopropyl group present in the ortho position in the aromatic ring of compound $\mathbf{4 b}$. Compounds $\mathbf{5 c}, \mathbf{5 d}$, and $\mathbf{5 e}$ were obtained in shorter reaction times (Figure 3).

The formation of compounds 5a-e was confirmed by IR, ${ }^{1} \mathrm{H} N M R$, and ${ }^{13} \mathrm{C} N M R$ spectroscopy. Upon analysis of the IR spectra, a vibration band with wavelengths ranging from 3131 to $3146 \mathrm{~cm}^{-1}$ was observed. This is characteristic of the stretching of the $\mathrm{C}_{s p}{ }^{2}-\mathrm{H}$ bond of the triazole ring, which is evidence for the formation of 1,2,3-triazoles, as described by Kaushik et al. (2016). In the ${ }^{1} H$ NMR spectrum, a signal with a multiplicity of the singlet type and integral equal to 1 from 7.73 to 7.81 ppm was found in all compounds $\mathbf{5 a - e}$, this signal can be attributed to the hydrogen of the triazole ring (Irfan et al. 2015, Santos et al. 2019). In the ${ }^{13} \mathrm{C}$ NMR spectra, the signals most characteristic of the formation of 1,4-disubstituted 1,2,3-triazoles were observed from 123.6 to $124.5 \mathrm{ppm}$ and 143.6 to $145.3 \mathrm{ppm}$, which are ranges corresponding to the $\mathrm{C}_{s p}{ }^{2}$ carbons of the triazole rings (Creary et al. 2012). Taken together, these results indicate the formation of the desired products.

\section{Evaluation of antioxidant activity}

The evaluation of the antioxidant activity of compounds $\mathbf{5 a - e}$ was carried out through two assays based on the detection of DPPH and ABTS radicals. These assays are widely used because of their simplicity, speed, and sensitivity (Huang et al. 2005). Antioxidant activity was expressed as the effective concentration of the sample that led to a $50 \%$ reduction $\left(\mathrm{EC}_{50}\right)$ in the initial concentration of DPPH (or ABTS) (Olugbami et al. 2015). The $\mathrm{EC}_{50}$ values obtained for compounds 5a-e are listed in Table I.

It was observed that compounds 5a-e had $\mathrm{EC}_{50}$ values ranging from 75.5 to $299.1 \mu \mathrm{g} / \mathrm{mL}$ in the DPPH assay and from 101.1 to $441.5 \mu \mathrm{g} /$

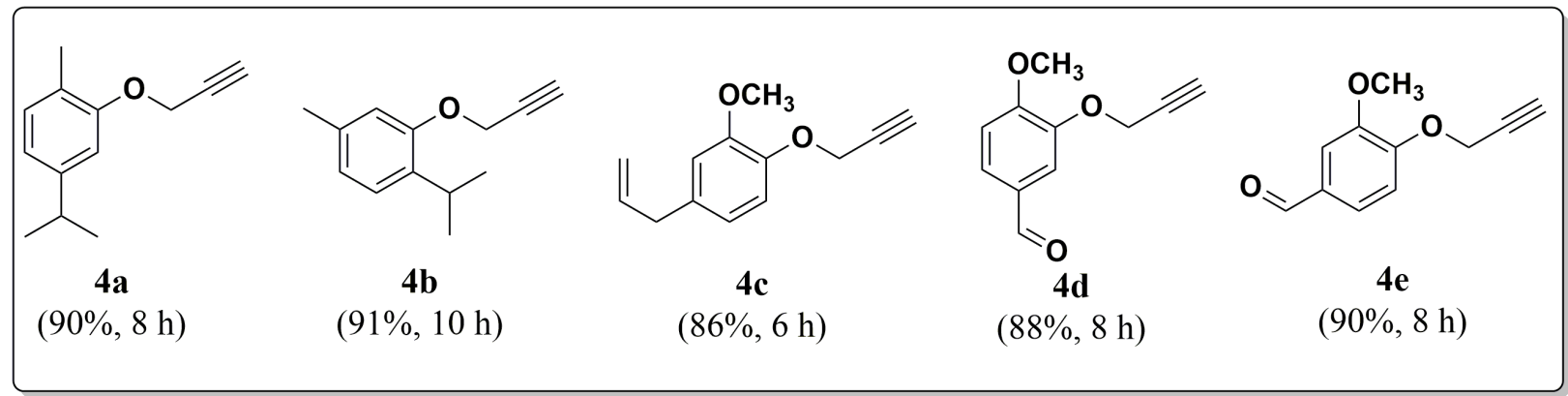

Figure 2. Synthesis of the alkynes terminal 4a-e. 
$\mathrm{mL}$ in the ABTS assay, indicating generally low antioxidant activities of $\mathbf{5 a - e}$ when compared to those of standards (ascorbic acid and TROLOX). Compound $\mathbf{5 e}$, derived from vanillin, was more active than compounds $\mathbf{5 a - d}$. This result corroborated with those of prior studies on antioxidant activity (Tai et al. 2011, Zhao et al. 2017). Studies have shown that vanillin can eliminate the free radical peroxyl, which simulates in vivo radical production in lipid peroxidation (Scipioni et al. 2018, Zhao et al. 2017), triggering antioxidative and anti-inflammatory neuroprotective activity (Gupta \& Sharma 2014).

Lee et al. (2011) reported the synthesis of a series of vanillin-based dendrimers with enhanced antioxidant properties. Scipioni et al. (2018) reported the strong antioxidant acivity (determined using the DPPH assay), ferric reducing ability of plasma, and oxygen radical absorbance capacity of derivatives obtained from the reductive amination between vanillin and various amines. Subsequently, Scipioni et al. (2019) reported the antioxidant activity of vanillin derivatives containing a tacrine or naphthalimido group.

Another important aspect in the search for new drug candidates is the prior evaluation of pharmacokinetic properties that makes investment in these molecules feasible; a significant number of compounds do not advance in clinical studies due to poor pharmacokinetic properties (Waterbeemd \& Gifford 2003). Therefore, the SwissADME bioinformatics platform was used to calculate the theoretical LogP values of compounds 5ae. Compounds 5a-e showed theoretical LogP values between 1.27 and 2.83. These values lie within the ideal range described by Barreiro \& Fraga (2015) and do not violat Lipinski's rule (Lipinski et al. 1997); thus, good oral absorption is expected for compounds $\mathbf{5 a - e . ~}$

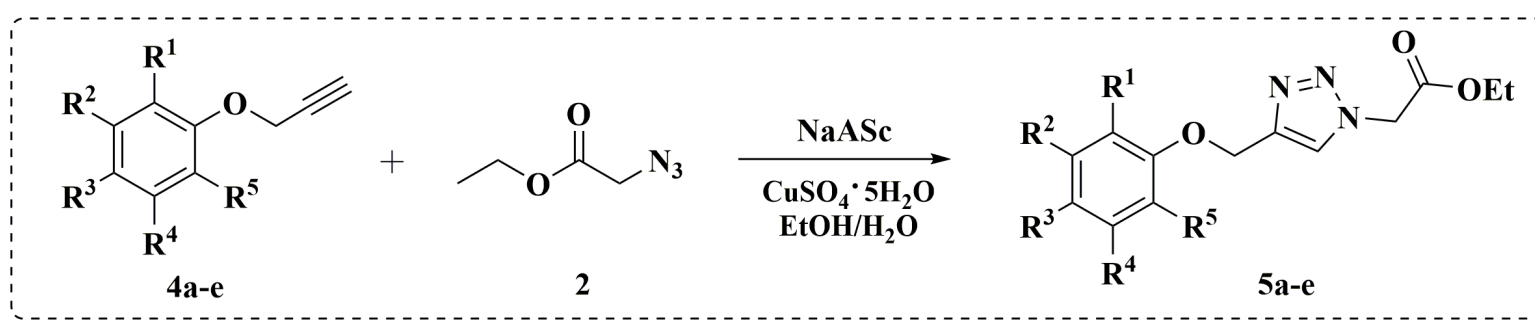<smiles>CCOC(=O)Cn1cc(COc2cc(C(C)C)ccc2C)nn1</smiles>

$2 \mathrm{~h}, 70 \%$<smiles>CCOC(=O)Cn1cc(COc2cc(C)ccc2C(C)C)nn1</smiles>

5b 2,3h, $60 \%$<smiles>C=CCc1ccc(OCc2cn(CC(=O)OCC)nn2)c(OC)c1</smiles>

$0,5 \mathrm{~h}, 80 \%$<smiles>CCOC(=O)Cn1cc(COc2cc(C=O)ccc2OC)nn1</smiles><smiles>CCOC(=O)Cn1cc(COc2ccc(C=O)cc2OC)nn1</smiles>

Figure 3. Derivatives of the new 1,4-disubstituted 1,2,3-triazoles semi-synthetic 5a-e. 
Table I. Antioxidant activity of compounds 5a-e.

\begin{tabular}{|c|c|c|}
\hline \multirow{2}{*}{ Sample } & \multicolumn{2}{|c|}{ EC $_{50} \mu \mathrm{g} / \mathbf{m L}$} \\
\cline { 2 - 3 } & DPPH & ABTS \\
\hline $5 a$ & $101.6 \pm 6.4$ & $164.1 \pm 9.0$ \\
\hline $5 b$ & $135.6 \pm 6.3$ & $441.5 \pm 18.5$ \\
\hline $5 c$ & $299.1 \pm 4.1$ & $101.1 \pm 5.2$ \\
\hline $5 d$ & $123.1 \pm 10.1$ & $107.8 \pm 5.5$ \\
\hline $5 e$ & $75.5 \pm 4.5$ & $112.1 \pm 7.6$ \\
\hline Ascorbic acid & $1.6 \pm 0.2$ & - \\
\hline TROLOX & - & $4.1 \pm 0.4$ \\
\hline
\end{tabular}

\section{CONCLUSION}

This work describes, for the first time, the synthesis and biological assessment of new 1,4-disubstituted 1,2,3-triazoles 5 a-e, which were obtained in yields ranging from $50 \%$ to $80 \%$. Moderate antioxidant potential was observed for synthesised compounds with $\mathrm{EC}_{50}$ values above $75.5 \mathrm{\mu g} / \mathrm{mL}$. In addition, through in silico studies, it was found that compounds 5a-e present satisfactory LogP values. Thus, the results presented in this study are the first steps towards the targeted development of new antioxidant agents.

\section{Acknowledgments}

The authors would like to thank the Conselho Nacional de Desenvolvimento Científico e Tecnológico (CNPq) development agencies (434012/2018-1) to Programa de Apoio a Núcleos Emergentes/Fundação de Amparo à Ciência e Tecnologia de Pernambuco (PRONEM/ FACEPE) (APQ-0476-1.06/14) for the financial support, to Fundação de Amparo à Ciência e Tecnologia de Pernambuco (FACEPE) (IBPG-1331-1.06/16; IBPG-00941.06/17) and Coordenação de Aperfeiçoamento de Pessoal de Nivel Superior (CAPES) for the scholarships granted, and the Analytical Center to the Departamento de Química Fundamental of the Universidade Federal de Pernambuco (DQF/UFPE) for the analyzes granted.

\section{REFERENCES}

AGALAVE SG, MAUJAN SR \& PORE VS. 2011. Click Chemistry: 1,2,3-Triazoles as Pharmacophores. Chem Asian J 6: 2696-2718.

ANEJA B ET AL. 2018. Natural Product-Based 1,2,3-Triazole/ Sulfonate Analogues as Potential Chemotherapeutic Agents for Bacterial Infections. ACS Omega 3: 6912-6930.

BARREIRO EJ \& FRAGA CAM. 2015 Química medicinal - As Bases Moleculares da Ação dos Fármacos, 3a ed., Porto Alegre: Artmed, p. 1-608.

BIAGI G, LIVI O, RAMACCIOTTI GL, SCARTONI V, BAZZICHI L, MAZZONI MR \& LUCACCHINI A. 1990. Superoxide dismutaselike activity of 1,2,3-triazole derivatives. Farmaco 45: 49-57.

CREARY X, ANDERSON A, BROPHY C, CROWELL F \& FUNK Z. 2012. Method for Assigning Structure of 1,2,3-Triazoles. J Org Chem 77: 8756-8761.

DHEER D, SINGH V \& SHANKAR R. 2017. Medicinal attributes of 1,2,3-triazoles: Current developments. Bioorg Med Chem 71: 30-54.

FERRONI C ET AL. 2017. 1,4-Substituted Triazoles as Nonsteroidal Anti-Androgens for Prostate Cancer Treatment. J Med Chem 60: 3082-3093.

FONG D, YEUNG J, MEICHSNER E \& ADRONOV A. 2019. Reactive Aqueous-Dispersible Polyfluorene-Wrapped Carbon Nanotubes Modulated with na Acidochromic Switch via Azide-Alkyne Cycloaddition. ACS Appl Polym Mater 1: 797-803.

GUPTA S \& SHARMA B. 2014. Pharmacological benefits of agomelatine and vanillin in experimental model of Huntington's disease. Pharmacol Biochem Behav 122: 122-135.

GURUNANJAPPA P, NINGAPPA MB \& KARIYAPPA AK. 2016. Synthesis of pyrazole fused pyran analogues: Antimicrobial, antioxidant, and molecular docking studies. Chem Data Collect 5-6: 1-11.

HATAI B \& BANERJEE SK. 2019. Molecular docking interaction between superoxide dismutase (receptor) and phytochemicals (ligand) from Heliotropium indicum Linn for detection of potential phytoconstituents: New drug design for releasing oxidative stress condition/ inflammation of osteoarthritis patients. J Pharmacogn Phytochem 8: 1700-1706. 
HUANG D, OU B \& PRIOR RL. 2005. The Chemistry behind Antioxidant Capacity Assays. J Agric Food Chem 53: 1841-1856.

HUSSAINI SMA, YEDLA P, BABU KS, SHAIK TB, CHITYAL GK \& KAMAL A. 2016. Synthesis and Biological Evaluation of 1,2,3-triazole tethered Pyrazoline and Chalcone Derivatives. Chem Biol Drug Des 88: 97-109.

IACOBUCCI C, REALE S, GAL JF \& ANGELIS D. 2015. Dinuclear Copper Intermediates in Copper(I)-Catalyzed AzideAlkyne Cycloaddition Directly Observed by Electrospray Ionization Mass Spectrometry. Angew Chem Int Ed 54: 3065-3068.

IRFAN M, ANEJA B, YADAVA U, KHAN SI, MANZOOR N, DANILIUC CG \& ABID M. 2015. Synthesis, QSAR and anticandidal evaluation of 1,2,3-triazoles derived from naturally bioactive scaffolds. Eur J Med Chem 93: 246-254.

KAUSHIK CP, KUMAR K, SINGH SK, SINGH D \& SAINI S. 2016. Synthesis, and antimicrobial evaluation of 1,4-disubstituted 1,2,3-triazoles with aromatic ester functionality. Arabian J Chem 9: 865-871.

KUMAR AD, NAVEEN S, VIVEK HK, PRABHUSWAMY M, LOKANATH NK \& KUMAR KA. 2016. Synthesis, crystal and molecular structure of ethyl 2-(4-chlorobenzylidene)3-oxobutanoate: Studies on antioxidant, antimicrobial activities and molecular docking. Chem Data Collect 5-6: 36-45.

LIAO Y, LU Q, CHEN G, YU Y, LI C \& HUANG X. 2017. RhodiumCatalyzed Azide-Alkyne Cycloaddition of Internal Ynamides: Regioselective Assembly of 5-Amino-Triazoles under Mild Conditions. ACS Catal 7: 7529-7534.

LIPINSKI CA, LOMBARDO F, DOMINY BW \& FEENEY PJ. 1997. Experimental and computational approaches to estimate solubility and permeability in drug discovery and development settings. Adv Drug Delivery Rev 23: 3-25.

LEE CY, SHARMA A, UZARSKI RL, CHEONG JE, XU H, HELD RA, UPADHAYA SK \& NELSON JL. 2011. Potent antioxidant dendrimers lacking pro-oxidant activity. Free Radical Biol Med 50: 918-925.

MOLONEY JN \& COTTER TG. 2017. ROS signalling in the biology of cancer. Semin Cell Dev Biol 80: 50-64.

OLUGBAMI JO, GBADEGESIN MA \& ODUNOLA O. 2015. A. In vitro free radical scavenging and antioxidant properties of ethanol extract of Terminalia glaucescens. Pharmacogn Res 7: 49-56.

RAHAL A, KUMAR A, SINGH V, YADAV B, TIWARI R, CHAKRABORTY S \& DHAMA K. 2014. Oxidative Stress, Prooxidants, and Antioxidants: The Interplay. Biomed Res Int 2014: 1-19.
RE R, PELEGRINI N, PROTEGGENTE A, PANNALA AYANG M \& RICEEVANS C. 1999. Antioxidant activity applying an improved ABTS radical cation decolorization assay. Free Radical Biol Med 26: 1231-1237.

ROSTOVTSEV VV, GREEN LG, FOKIN VV \& SHARPLESS KB. 2002. A Stepwise Huisgen Cycloaddition Process: Copper(I)Catalyzed Regioselective "Ligation" of Azides and Terminal Alkynes. Angew Chem Int Ed 41: 2596-2599.

SANTOS CS, OLIVEIRA RJ, OLIVEIRA RN \& FREITAS JCR. 2020. 1,2,3- Triazoles: general and key synthetic strategies. Arkivoc part I : 219-271.

SANTOS T, COELHO CM, ELIAS TC, SIQUEIRA FS, NORA ESSD, CAMPOS MMA, SOUZA GAP, COELHO LFL \& CARVALHO DT. 2019. Synthesis and Biological Evaluation of New EugenolDerived 1,2,3- Triazoles as Antimyco bacterial Agents. J Braz Chem Soc 30: 1425-1436.

SATAPUTE P, SANAKAL RD, MULLA SI \& KALIWAL B. 2019. Molecular interaction of the triazole fungicide propiconazole with homology modelled superoxide dismutase and catalase. Environmental Sustainability 2: 429-439.

SCIPIONI M, KAY G, MEGSON I \& LIN PKT. 2018. Novel vanillin derivatives: Synthesis, anti-oxidant, DNA and cellular protection properties. Eur J Med Chem 143: 745-754.

SCIPIONI M, KAY G, MEGSON I \& LIN PKT. 2019. Synthesis of novel vanillin derivatives: novel multi-targeted scaffold ligands against Alzheimer's disease. Med Chem Comm 10: 764-777.

SILVA TMS, SILVA S, CAMARA CA, LINS ACS, BARBOSA-FILHO JM, DA SILVA EMS, FREITAS BM \& DOS SANTOS FAR. 2006. Chemical composition and free radical scavenging activity of pollen loads from stingless bee Melipona subnitida Ducke. J Food Compos Anal 19: 507-511.

TAI A, SAWANO T, YAZAMA F \& ITO H. 2011. Evaluation of antioxidant activity of vanillin by using multiple antioxidant assays. Biochim Biophys Acta 1810: 170-177.

TAN BL, NORHAIZAN ME, LIEW W \& RAHMAN HS. 2018. Antioxidant and Oxidative Stress: A Mutual Interplay in Age-Related Diseases. Front Pharmacol 9: 1162-1190.

TEIXEIRA RR, GAZOLLA PAR, DA SILVA AM, BORSODI MPG, BERGMANN BR, FERREIRA RS, VAZ BG, VASCONCELOS GA \& LIMA WP. 2018. Synthesis and leishmanicidal activity of eugenol derivatives bearing 1,2,3-triazole functionalities. Eur J Med Chem 146: 274-274.

WATERBEEMD HVD \& GIFFORD E. 2003. ADMET in silico modelling: towards prediction paradise?. Nat Rev Drug Discov 2: 192-204. 
ZHANG L ET AL. 2016. A highly selective fluorogenic probe for the detection and in vivo imaging of $\mathrm{Cu} / \mathrm{Zn}$ superoxide dismutase. Chem Commun 52: 9093-9096.

ZHAO Z, SUN J, SUN B, ZHAO M, ZHENG F, HUANG M, SUN $X$ \& LI H. 2017. Intracellular antioxidant effect of vanillin, 4-methylguaiacol and 4-ethylguaiacol: three components in Chinese Baijiu. RSC Adv 7: 46395-46405.

\section{SUPPLEMENTARY MATERIAL}

\section{Figures S1 to S22. Concerning the spectra of synthesized compounds.}

\section{How to cite}

CUNHA LIMA JA, DE FARIAS SILVA J, SANTOS CS, CAIANA RRA, DE MORAES MM, DA CÂMARA CAG \& FREITAS JCR. 2021. Synthesis of new 1,4-disubstituted 1,2,3-triazoles using the CUAAC reaction and determination of their antioxidant activities. An Acad Bras Cienc 93: e20201672. DOI 10.1590/0001-3765202120201672.

Manuscript received on October 23, 2020;

accepted for publication on February 5, 2021

\section{JOSEFA A. DA CUNHA LIMA ${ }^{1}$}

https://orcid.org/0000-0002-2004-3804

\section{JADSON DE FARIAS SILVA ${ }^{1}$}

https://orcid.org/0000-0002-6039-2857

\section{COSME S. SANTOS}

https://orcid.org/0000-0001-7812-9494

RODRIGO R.A. CAIANA ${ }^{2}$

https://orcid.org/0000-0002-7935-6143

MARCÍLIO M. DE MORAES ${ }^{1}$

https://orcid.org/0000-0002-7597-6775

CLAUDIO A.G. DA CÂMARA ${ }^{1}$

https://orcid.org/0000-0002-8331-9302

JULIANO C.R. FREITAS 1,2

https://orcid.org/0000-0003-4617-4084

${ }^{1}$ Universidade Federal de Campina Grande, Centro

de Educação e Saúde, Acesso Professora Maria Anita

Furtado Coelho, s/n, 58175-000 Cuité, PB, Brazil

${ }^{2}$ Universidade Federal Rural de Pernambuco,

Departamento de Química, Rua Dom Manoel de

Medeiros, s/n, 52171-900 Recife, PE, Brazil

Correspondence to: Juliano Carlo Rufino de Freitas

E-mail: julianocrufino@pq.cnpq.br

\section{Author contributions}

LIMA JAC, SILVA JAC and SANTOS CS performed the synthesis, characterization of the compounds and the writing of the manuscript. CAIANA RRA, CAMARA CAG and MORAES MM conducted the experiments of antioxidant activity and data analysis. FREITAS JCR participated in the writing of the manuscript and project supervision.

\section{(cc) BY}

